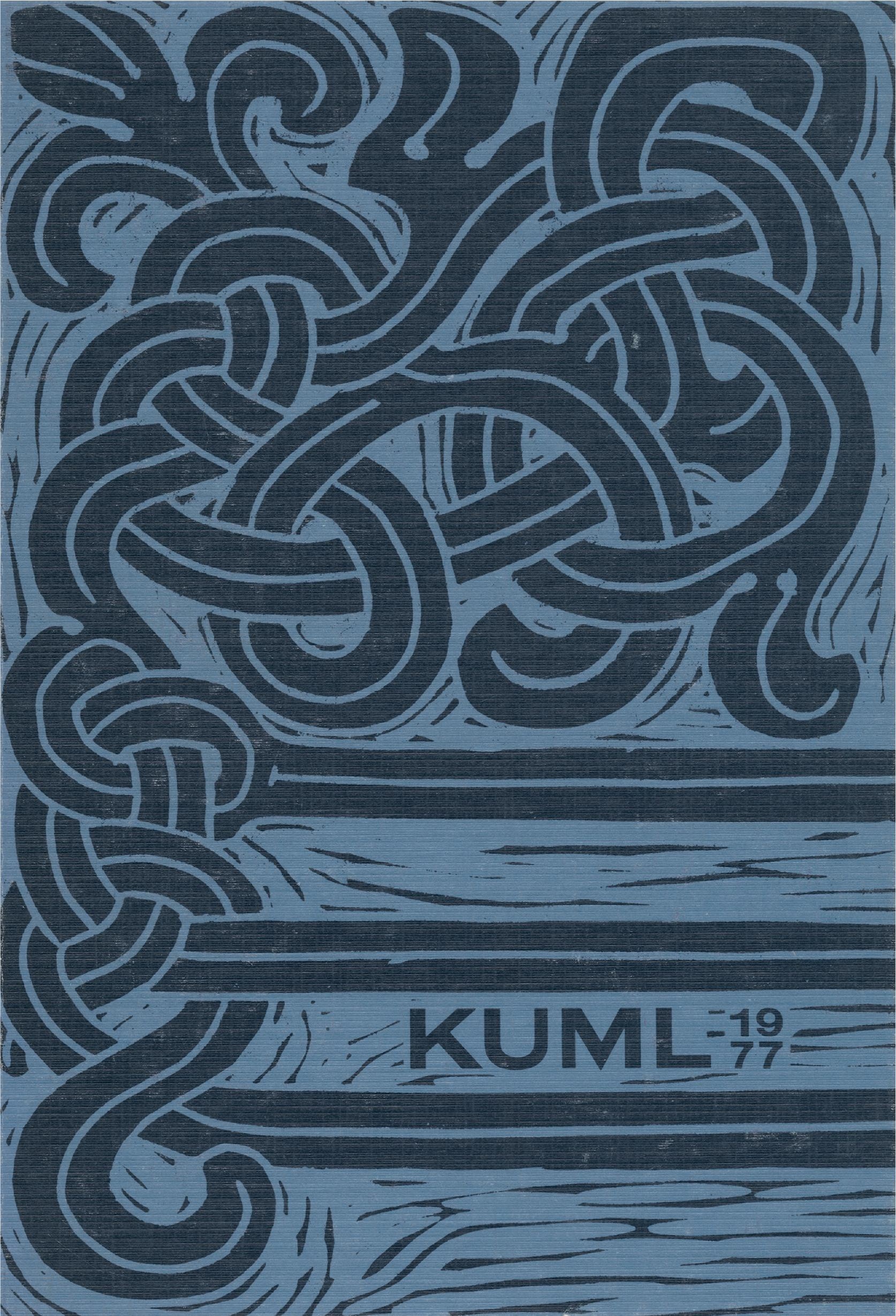




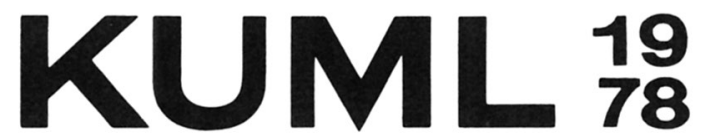

ÅRBOG FOR

JYSK ARKÆOLOGISK SELSKAB

With Summaries in English

I kommission hos Gyldendalske Boghandel, Nordisk Forlag, København 1979 
OMSLAG:

Fantasi over ansigtskar fra tragtbægerkulturen.

Redaktion: Poul Kjarum

Tilretteleggelse og omslag: Flemming Bau

Tryk: Special-Trykkeriet, Viborg a-s

Skrift: Baskerville 11 pkt.

Papir: Stora G-point $120 \mathrm{gr}$.

Copyright 1979 by Jysk Arkæologisk Selskab

ISBN 87-01-96171-3 


\section{INDHOLD/CONTENTS}

Søren H. Andersen: Aggersund. En Ertebølleboplads ved Limfjorden ................. 7

Aggersund. An Ertebølle settlement on the Limfjord .......................... 50

Ulrik Mohl: Aggersund-bopladsen zoologisk belyst. Svanejagt som årsag til bosættelse?

Zoological analysis of the Aggersund settlement: a special-purpose camp for hunting swans? ............................................................. 72

Søren H. Andersen: Flade, skælhuggede skiver af Brovst-type ........................ 77

The scale-worked flakes, a newly-discovered artifact type from the early

Ertebølle culture of western Denmark ................................................ 96

Klaus Ebbesen: Stenalderlerkar med ansigt ……....................................... 99

Stone Age face pots …….......................................................... 112

Anne Birgitte Gebauer: Mellemneolitisk tragtbægerkultur i Sydvestjylland. En analyse af keramikken ............................................................ 117

The Middle Neolithic Funnel Beaker Culture in south-west Jutland. An analysis of the pottery ............................................................... 150

Peter Rowley-Conwy: Forkullet korn fra Lindebjerg. En boplads fra ældre

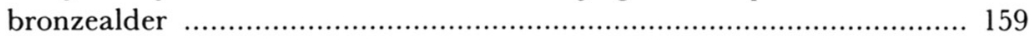

The carbonized grain from Lindebjerg ........................................... 167

Dafydd Kidd: En guldgubbe fra Bornholm .............................................. 173

An anthropomorphic gold figure from Bornholm .............................. 176

Søren Nancke-Krogh: Ribehesten og dens slægtninge ................................... 179

The Ribe horse and its relatives ....................................................... 189

Jan Kock: Brovold. En befæstet bebyggelse fra tidlig middelalder .................. 193

Brovold - a fortified settlement from the early Middle Ages .................. 219

Else Roesdahl: Bagergadefundet i Svendborg. Affald fra et middelalderligt pottemagerværksted .......................................................................... 223

The Bagergade find in Svendborg. Wasters from a medieval pottery

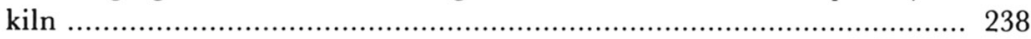

Ingrid Nielsen: En middelalderlig seglstampe fra Tvilum ...................................241

A medieval seal matrix from Tvilum .............................................. 243

Niels Abrahamsen: Magnetisk datering af ovnanlæg fra Rye Sønderskov ............. 245

Paleomagnetic dating of a kiln from Rye Sønderskov ............................ 249 


\title{
FLADE, SKÆLHUGGEDE SKIVER AF BROVST-TYPE
}

\author{
Fremstillingsteknikken af de tidligste tværpile i Jylland
}

Af Søren H. Andersen

Da tværpilen indtager en fremtrædende plads blandt Ertebøllekulturens karakteristiske redskabsformer, er det naturligt, at denne type ved flere lejligheder har været genstand for grundige analyser i den arkæologiske litteratur; det gælder ikke blot de færdige tværpile, men også den praktiserede fremstillingsteknik (1).

Imidlertid har de senere års nye udgravninger af jyske Ertebøllebopladser på vigtige punkter både uddybet og samtidig ændret vor opfattelse af fremgangsmåden ved fremstilling af de ældste tværpile (2).

Ved udgravningen af kystbopladsen »Brovst« med kulturlag fra yngre Kongemose- og Ertebøllekultur (3) blev der i de dybeste (og ældste) lag (lag 2, 11 og 8) fundet en ny oldsagsform, skælhuggede skiver, som ikke tidligere er beskrevet i den arkæologiske litteratur.

Råmaterialet er grove, tykke skiver, der i langt de fleste tilfælde stammer fra ydersiden af en flintknold og derfor har skorpe (cortex) på over- eller rygsiden, fig. la-d.

Omridset er gennemgående uregelmæssigt. Ved udvælgelsen af egnede råemner kan der dog spores en tendens til at foretrække stykker med et tilnærmet, rektangulært omrids.

I nogle få tilfælde er der også benyttet naturlige, varme- eller frostafsprængte yderskiver af flintknolde; i disse tilfælde er der dog kun anvendt skiver, hvor begge sider er regelmæssigt hvælvede. Sådanne »naturskiver« er f.eks. repræsenteret i fundet fra Ø. Jølby (tidlig Ertebøllekultur) fig. 6. (4).

Størrelsen varierer fra stykker, hvis længde-bredde mål er ca. $3 \times 3 \mathrm{~cm}$ til noget større emner på ca. $8 \times 8 \mathrm{~cm}$. Den almindeligste størrelse ligger midt imellem yderpunkterne. Den største tykkelse ligger mellem 0,7 cm og $2 \mathrm{~cm}$.

Det er imidlertid ikke så meget stykkernes form og størrelse som tilhugningen, der er karakteristisk.

Tilhugning: De skælhuggede skiver er især karakteriseret ved en særlig tilhugning i slagbuleenden, hvorved en del af den er borthugget, fig. 1-5. Ved forarbejdningen er der dannet en regelmæssig kant, vinkelret på 

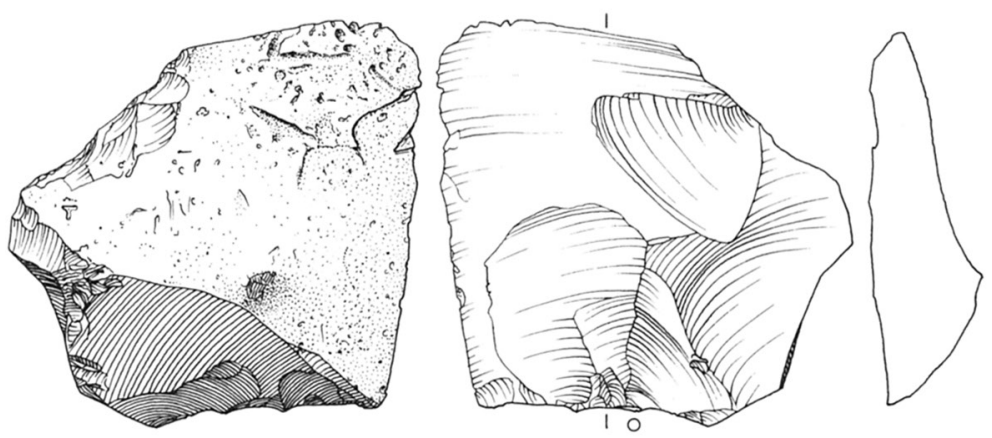

$1 b$
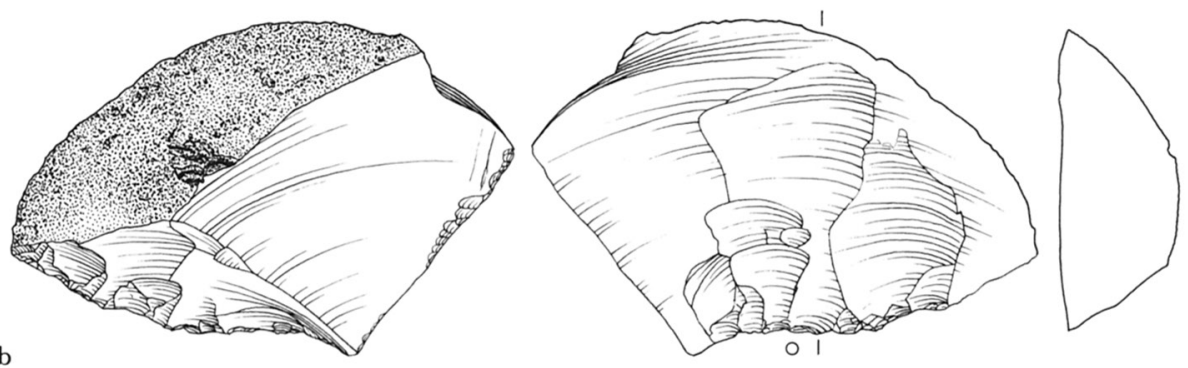

$1 \mathrm{c}$
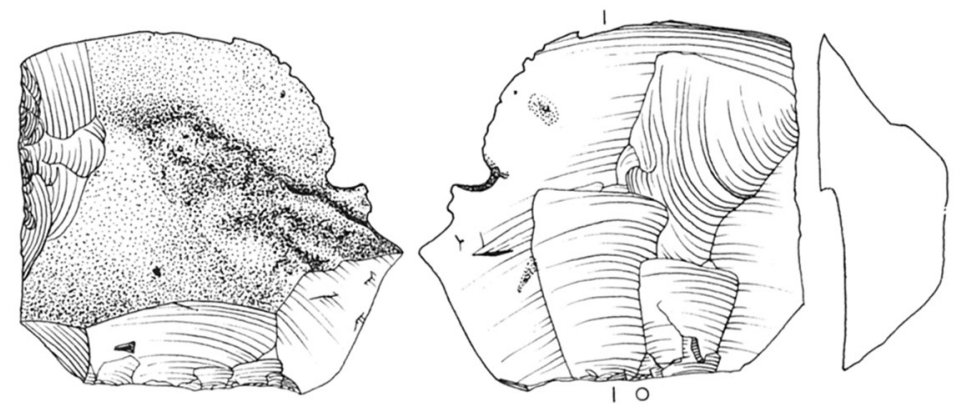

$1 d$
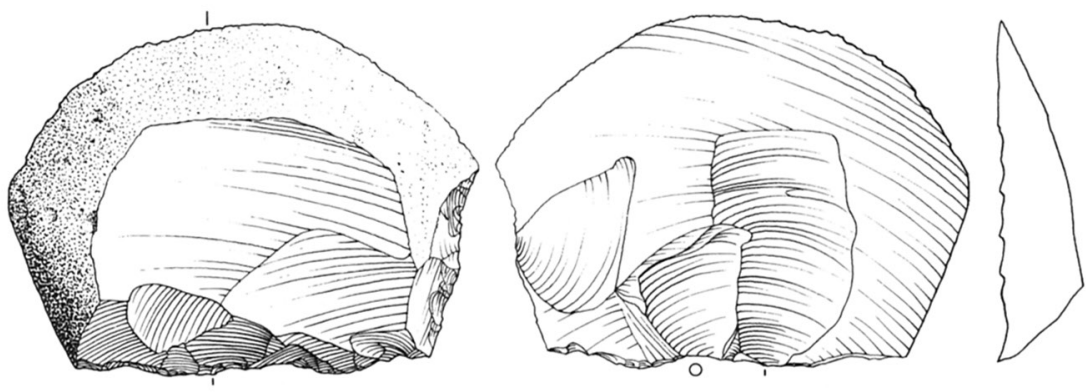

Fig. 1: Skælhuggede skiver fra lag 2 og 11 ved Brovst. 3:4

Scale-worked flakes from Brovst layers 2 and 11. 
emnets længdeakse, fig. 1. Kanten, der er omhyggeligt tilhugget og retoucheret, er i langt de fleste tilfælde lige eller svagt konkav, fig. 1-3, men kan dog også være konveks, fig. 4-5.

Tilhugningen, der udgår fra under- eller bugsiden, har fjernet hele partiet omkring slagbuleenden.

Retoucheringen er regelmæssig og kontinuerlig og danner en vinkel på ca. $60^{\circ}-80^{\circ}$ med bugsiden.

I nogle få tilfælde er kanttilhugningen foregået ved, at hele slagbulepartiet er afhugget ved et enkelt, tværgående slag, fig. 10a.

På mange stykker er der to eller flere bearbejdede kanter på samme afslag, fig. $\operatorname{la~og~c~og~2a.~I~sådanne~tilfælde~findes~de~retoucherede~kanter~}$ altid ud for skivens tykkeste og mest hvælvede partier, fig. 1, og kanterne danner ofte en ret vinkel i forhold til hinanden, fig. 1c og d.

På samtlige stykker ses ar efter flade, skællede afhugninger 'fliser' på bugsiden, hvor de altid udgår fra den eller de retoucherede kanter fig. 1-10. Da hovedparten af skiverne kun har én tilhugget kant i slagbuleenden, findes den skællede afhugning i de fleste tilfælde på slagbuleendens bugside. Der kan enten være spor efter én enkelt eller flere tætsiddende

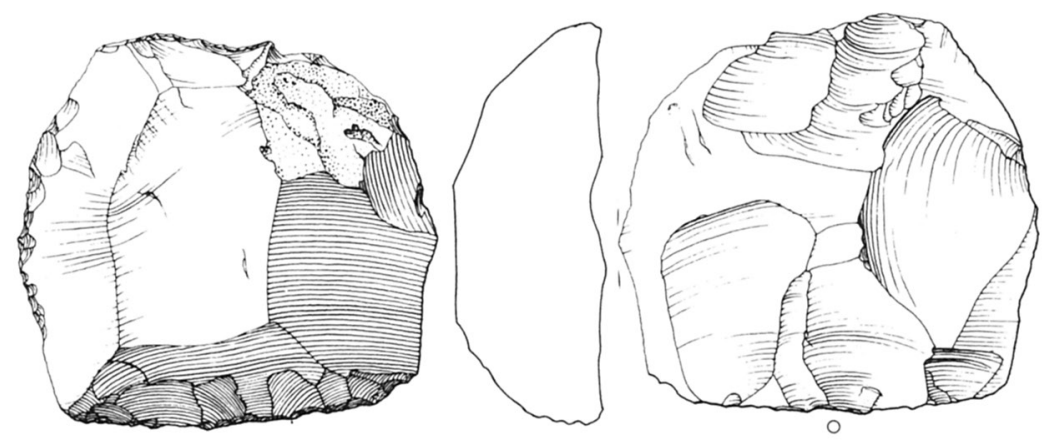

$2 \mathrm{a}$

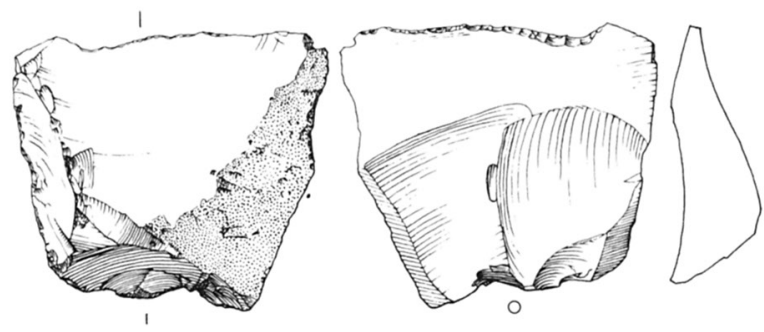

Fig. 2: Skælhuggede skiver fra Agdruplund. 3:4

Scale-worked flakes from Agdruplund. 

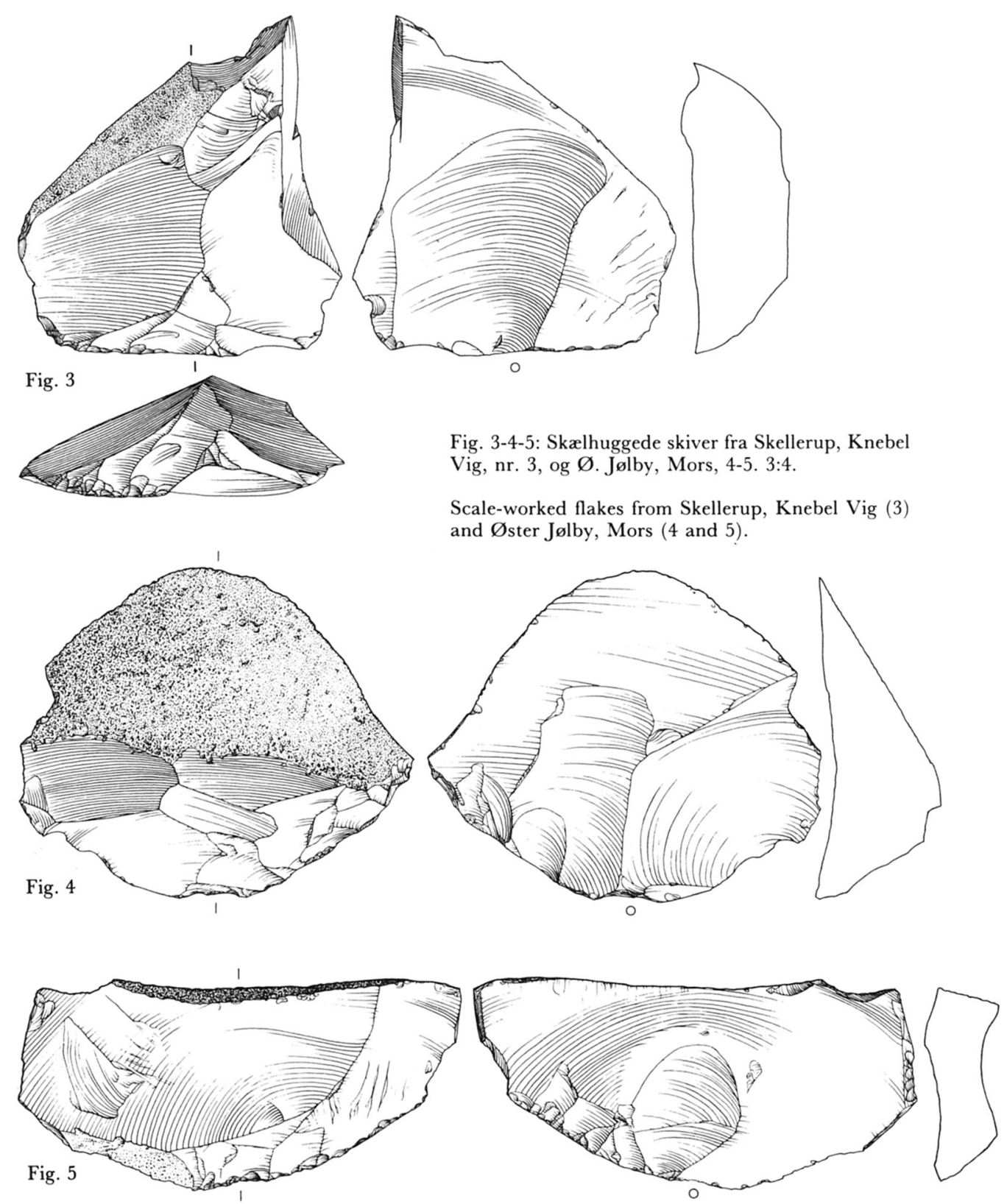

Fig. 3-4-5: Skælhuggede skiver fra Skellerup, Knebel Vig, nr. 3, og Ø. Jølby, Mors, 4-5. 3:4.

Scale-worked flakes from Skellerup, Knebel Vig (3) and Øster Jølby, Mors (4 and 5).

afspaltninger, der tilsammen dækker et større parti af bugsiden, fig. 1-2. I enkelte tilfælde kan der også være afhugget fliser i distalenden, fig. 7 .

Normalt er der kun afhugget ét par eller få fliser fra bugsiden. Slagpunkterne er placeret således, at afslagene hele tiden bliver tilnærmelsesvis cirkulære (og altså ikke »lapper« ind over hinanden), se f.eks. fig. la. 
I nogle tilfælde er der slået gentagne gange på samme sted, hvorved flere successive fliser er afhugget. I disse tilfælde bliver de sidste afhug flade og uregelmæssige i omrids og tværsnit, f.eks. fig. 10b.

En analyse af rækkefølgen mellem de forskellige spor af forarbejdning på de skælhuggede skiver viser, at afhugning af »dobbeltkonvekse fliser « på bugsiden har været sidste led i tilhugningen (udnyttelsen) af disse stykker.

Det fremgår samtidig, at de(n) tilhuggede kant(er) må være lavet, for at man har kunnet foretage afhugning af fliserne fra bugsiden. Den tildannede kant har altså fungeret som slagflade for den efterfølgende fremstilling af de dobbeltkonvekse fliser.

En slagflade, dannet ved retouchering, kendes også fra andre oldsagsformer, f.eks. stikler (kant- og tværstikler); her fungerer en retoucheret kant som platform for det følgende stikkelafslag (5).

Fig. 6
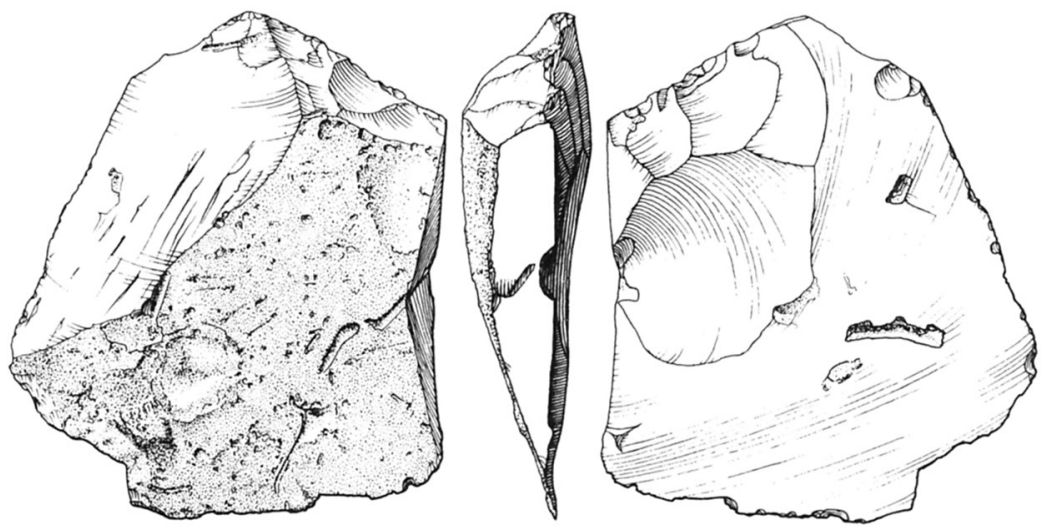

Fig. 7a

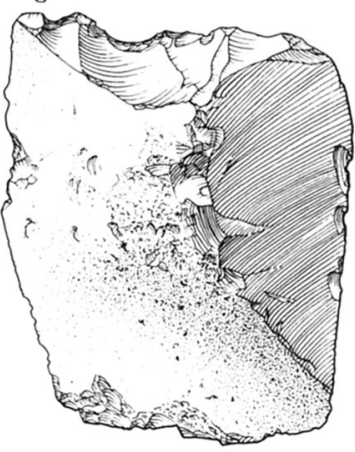

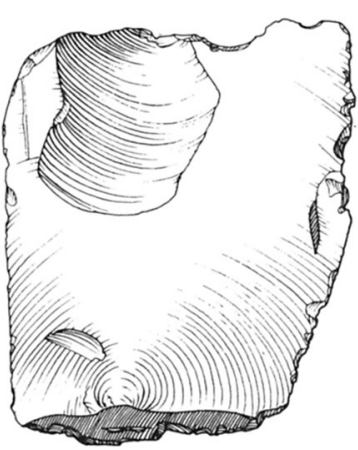

Fig. $7 \mathrm{~b}$

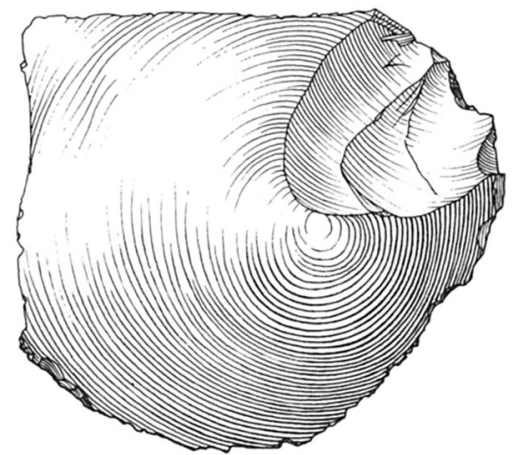

Fig. 6-7: Skælhuggede skiver fra $\varnothing$. Jølby, Mors. Fig. 7b er på »natur-skive« Fig. 7a viser afhug i distalenden. 3:4.

Scale-worked flakes from Øster Jølby, Mors. Fig. 7b shows 'natural flake' and fig. 7a shows those with flaking at the distal end. 

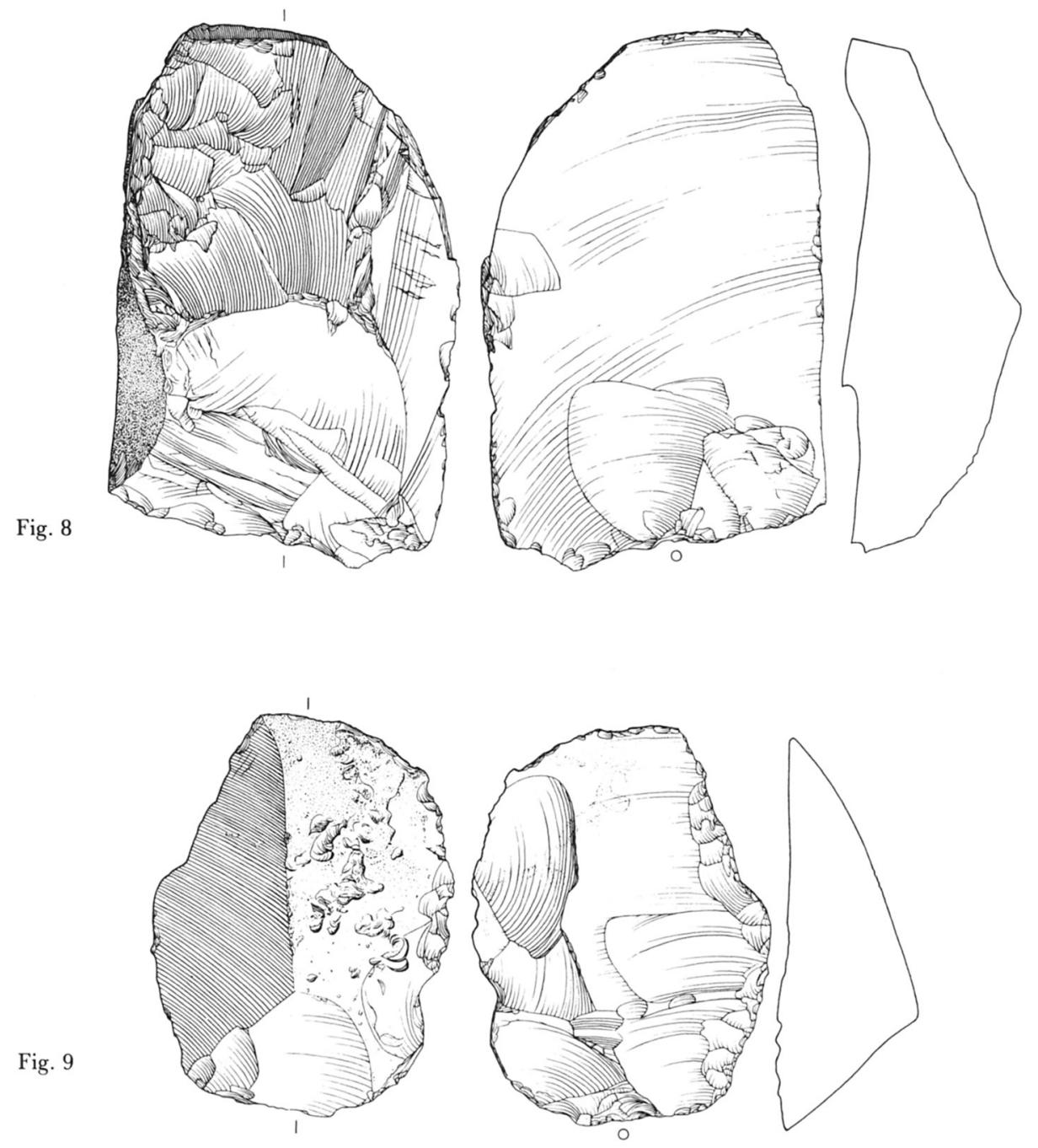

Fig. 8-9: Skælhuggede skiver fra bopladserne Engelsgård (fig. 8) og Frederiksdal (fig. 9) i Norsminde fjord. $3: 4$,

Scale-worked flakes from the settlements at Engelsgård (fig. 8) and Frederiksdal (fig. 9) on Norsminde fiord.

Fig. 10: Skælhuggede skiver fra Brovst lag 2. Afslagets slagbuleparti er borthugget med et enkelt slag (fig. 10a). De øvrige fra Norslund lag 3 (fig. 10b-c) og Ringkloster (fig. 10d). 3:4.

Scale-worked flakes from Brovst layer 2. The bulb of percussion has been removed with a single blow (fig. 10a). The other are from Norslund layer 3 (fig. 10b-c) and Ringkloster (fig. 10d). 

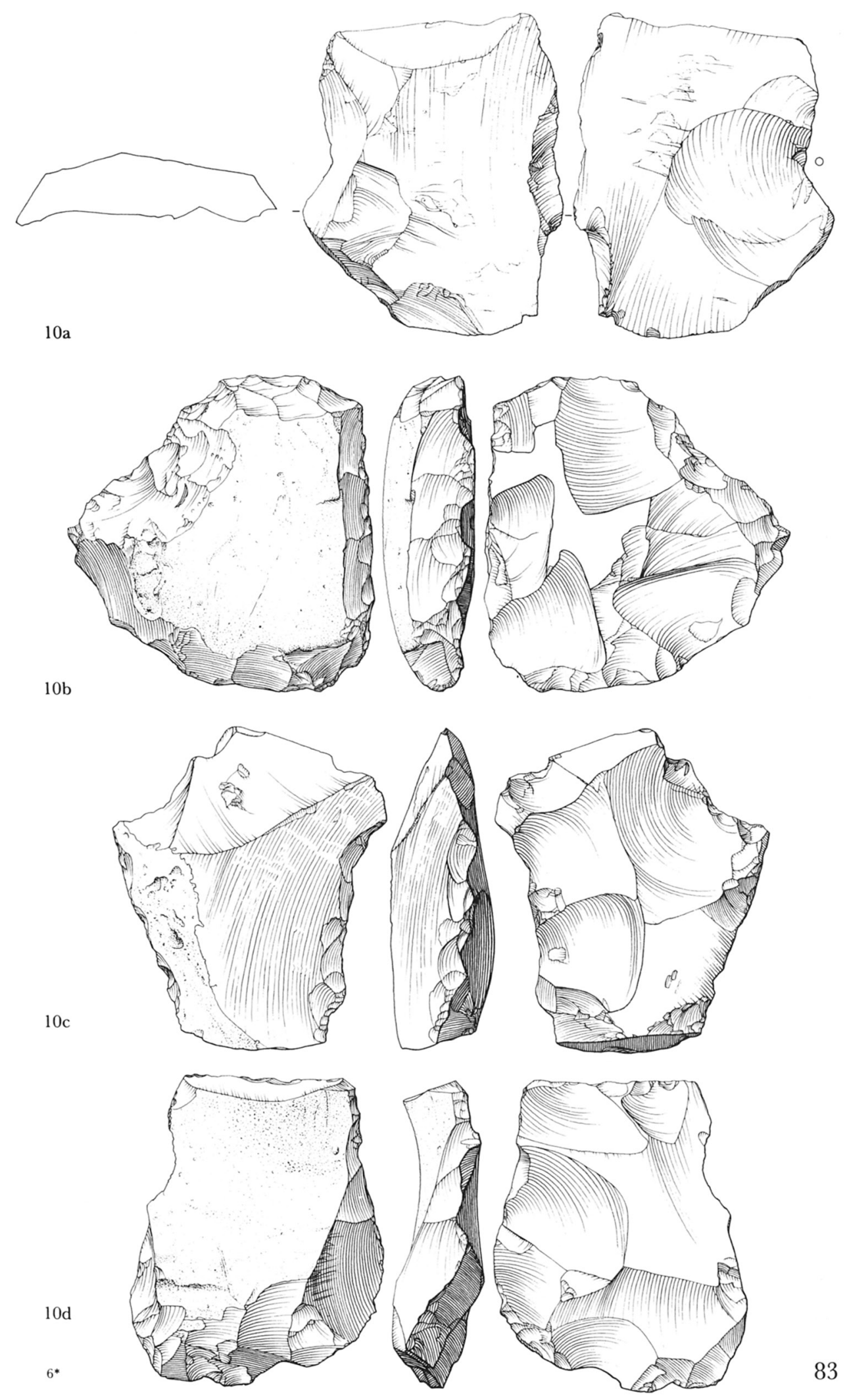
Der er dog også iagttaget få stykker, hvor der er afhugget fliser uden at der samtidig ses en retoucheret kant, f.eks. fig. 10a og d.

Der er her tale om udvælgelse af en helt speciel type råmateriale, hvor der ved en kant allerede er en flade med en egnet, stejl vinkel mod bugsiden. Sidefladen danner i disse tilfælde en 'naturlig platform' for den efterfølgende afhugning af 'fliser', cf. fig. 7b.

Den fuldstændig konsekvente placering af de(n) tilhuggede kant(er) først og fremmest i råemnets slagbuleende, men også ud for undersidens øvrige hvælvede dele, viser, at det er disse partier, der må have været bedst egnede som udgangspunkt for den påfølgende afhugning af de dobbeltkonvekse fliser.

Sammenfattende viser ovenstående beskrivelse og analyse af de flade, skælhuggede skiver, at det er et specielt restprodukt, fremkommet ved fremstilling af en eller flere små fliser.

De her beskrevne skælhuggede skivers ensartede form, tilhugning og afspaltninger på bugsiden viser, at de ikke er tilfældigheder, men en form, der tydeligt adskiller sig fra de tidligere kendte og beskrevne typer fra Danmarks ældre stenalder.

Typen viser nogen lighed med skraberne, men adskiller sig dog klart fra disse på flere væsentlige punkter, bl.a. ved den uregelmæssige form, retoucheringens forløb, dens vinkel og placering.

Ved Brovst optrådte de i stort tal i de nævnte lag, og typen blev senere også påvist ved udgravninger af andre tidlige, jyske kystbopladser. Den ensartede udformning, såvel på de enkelte bopladser som i et større geografisk område, viser, at der er tale om en fast udformet type.

De nyfundne stykker adskiller sig klart med hensyn til størrelse, form og tilhugning fra de "skælhuggede flintstykker«, der er beskrevet af C. J. Becker i forbindelse med bornholmske bopladser fra Maglemosekulturen (6).

»Brovst-skiverne« er først og fremmest større og mere uregelmæssige end de af Becker beskrevne »skælhuggede flintstykker«. Hertil kommer, at de nyfundne former altid kun viser fladeafspaltning på een side, mens de "skællede stykker" har afhugninger på begge sider og derfor har ovalt tværsnit. »Brovst-typen « har derimod altid trekantet eller halvcirkelformet tværsnit, f.eks. fig. 1-4.

Et andet, væsentligt træk, der adskiller den nye form fra Beckers skælhuggede flintstykker, er den konsekvente tilhugning i råemnets slagbuleende.

På fig. 15 er gengivet de enkelte trin i tilhugningen af en flad, skælhugget skive og en dobbeltkonveks flis.

Fliserne: Arrene på de skællede skiver viser, at de små, afslåede fliser har været runde eller ovale i omrids (tværmål $1-2 \mathrm{~cm}$ ), at de har haft et 

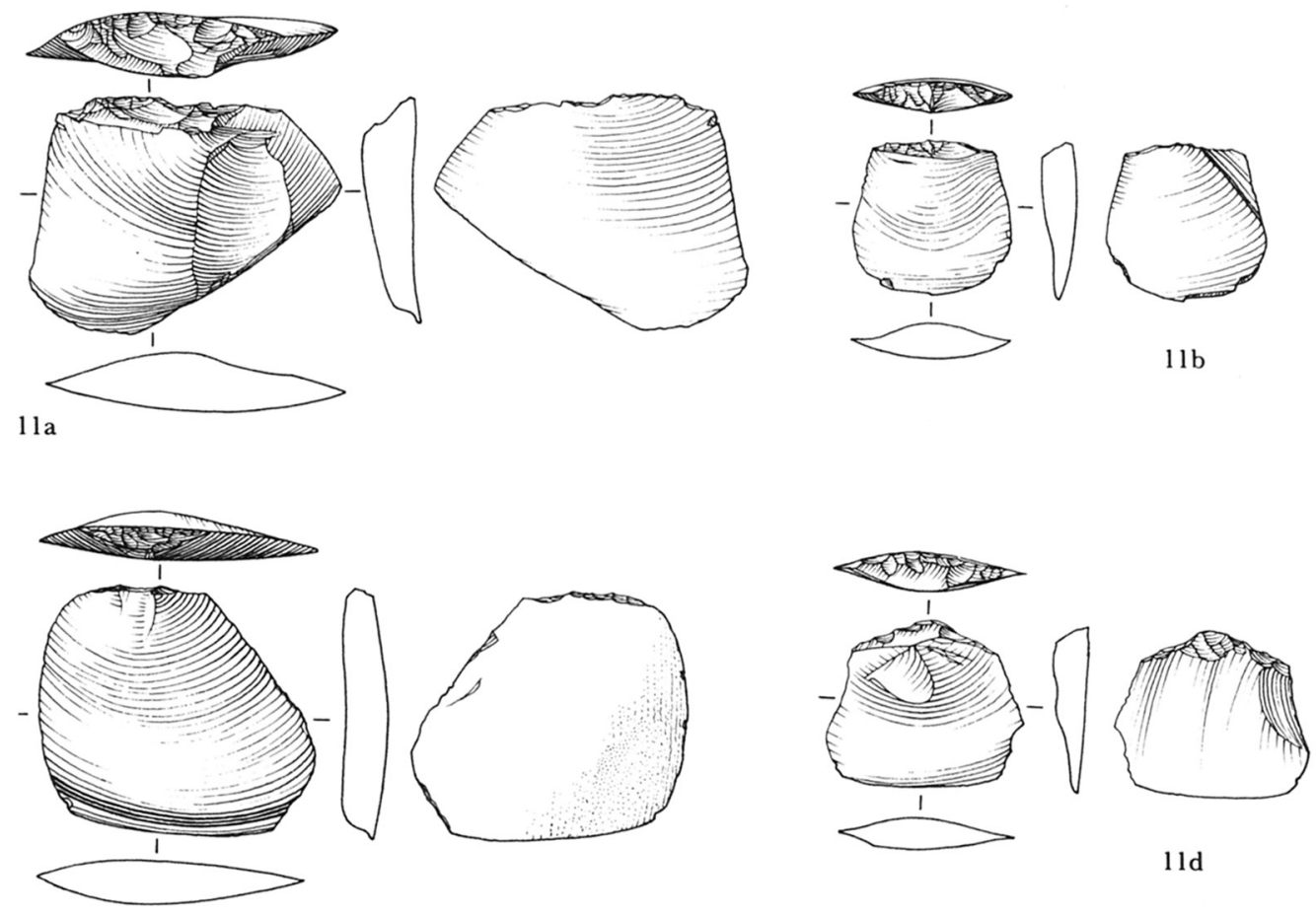

$11 d$

$11 \mathrm{c}$

Fig. 11: Små skiveafslag »fliser « fra Ø. Jølby, Mors 1:1. Small trimming flakes from Øster Jølby, Mors.
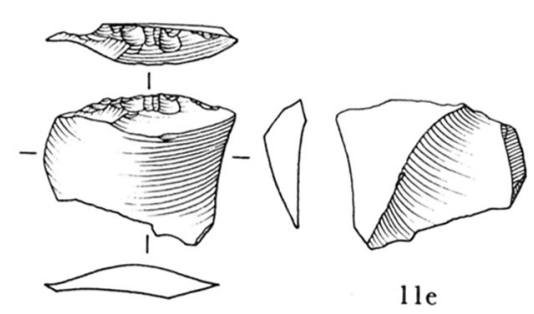

spidsovalt/dobbeltkonvekst tværsnit og har haft glatte sideflader. Tykkelsen har været ca. 1-3 mm. Deres slagbule har været flad og svagt udviklet, hvorved deres underste eller yngste side også får et fladt forløb. Endelig må deres platformrest vise spor af retouchering fra kanten på den skællede skive, fig. 11.

Den helt konsekvente placering af afhugningen af de små fliser i råemnernes slagbuleende og ud for de mest hvælvede dele af bugsiden må betyde, at det har været systematisk tilstræbt at give disse fliser et symmetrisk, dobbeltkonvekst tværsnit og regelmæssige, glatte sideflader. Disse krav til slutprodukterne (fliserne) kan jo netop kun opfyldes ved afhugning ud for primærmaterialets slagbule, da det kun er her, at overfladen er jævnt hvælvet og uden ar. 
Den hyppige forekomst af skælhuggede skiver og det store antal ar af "dobbeltkonvekse fliser « på disse viser, at de er blevet fremstillet i et meget stort antal.

Afslag, der opfylder de næunte form- og størrelseskriterier, findes da også lejlighedsvis i fundstoffet fra netop de bopladser, hvor der er påvist skællede skiver, fig. 11. Omvendt kendes de ikke fra fund, hvor typen mangler, f.eks. de øvre lag ved Brovst (lag 5-6-7) (7).

De små, dobbeltkonvekse fliser adskiller sig fra det øvrige afslagsmateriale ved den karakteristiske form, og ved at de kun har en meget lille platformrest, der viser retouchering.

Sammenholdes det lille antal fliser, som i dag kan påvises i materialet, med den mængde, der oprindelig må have været tilstede, fremgår det, at hovedparten af afslagene enten må være fjernet fra bopladserne eller videreforarbejdet til andre redskaber.

Spørgsmålet er da, om der i det øvrige fundstof evt. kan påvises redskaber, hvis størrelse og form tyder på, at de er fremstillet af sådanne fliser.

Den eneste oldsag, der med hensyn til størrelse, form og antal opfylder de ovennævnte betingelser, er tværpilen. Det er karakteristisk, at tværpilene fra de tidlige jyske Ertebøllebopladser netop meget ofte er fremstillet af små skiver med dobbeltkonvekst tværsnit og glatte sideflader - et forhold, der første gang blev påvist i forbindelse med publikationen af Norslundbopladsen. Her blev det iagttaget, at en del af tværpilene fra de dybeste og ældste lag (lag 3 og 4) var fremstillet af den ovennævnte type fliser, mens denne art råmateriale ikke havde været anvendt $\mathrm{i}$ forbindelse med tværpilene fra de øvre lag (lag 2, 1 og 0) (8).

Fra Norslunds lag 3 er 11 stk. ud af 68 stk. tværpile (16,2\%) fremstillet af sådanne fliser; ved Ø. Jølby på Mors er $21 \%$ af tværpilene af små fliser (9). Også fra Brovst (lag 2, 11, 8 og nedre del af lag 4) og andre tidlige, jyske Ertebøllefund er tværpile, lavet af denne type råmateriale, almindelige.

Tværpilene fra de nævnte horisonter på bopladserne Norslund, Brovst og Ø. Jølby tilhører fortrinsvis den retæggede type med parallelle eller let konkave sidekanter (som Danske Oldsager, I, nr. 98 og 99), men der findes dog også tværpile af den skævæggede variant (D.O. I, nr. 101-102), der er lavet på fliser, cf. fig. 12-13.

Der er i denne forbindelse grund til at bemærke, at den dominerende form blandt de tidligste, jyske tværpile er typen med ret æg og parallelle eller svagt konkave sidekanter, mens de skævæggede varianter er mindre fremtrædende.

Dette forhold er klart forskelligt fra iagttagelserne på de jæungamle "østdanske« (sjællandske) bopladser, hvor de skævæggede tværpile-varianter tværtimod synes at være dominerende (9). 
At dobbeltkonvekse fliser i så høj grad har fundet anvendelse som råmateriale til tværpile, må skyldes funktionelle krav til pilene m.h.t. et regelmæssigt-spidsovalt tværsnit med plane sider uden ar.

Til belysning af dette kan nævnes, at tværpilene i yngre stenalder ofte er lavet på fliser af slebne økser (10). Her er det øksens glatte, hvælvede sideflader, der udnyttes på samme måde som bugsiden på de skælhuggede skiver.

De skællede skiver må derfor tolkes som et særpræget affaldsprodukt, fremkommet ved fremstilling af tværpile.

Det må dog samtidig anføres, at de skællede skiver selvfølgelig ikke er den eneste »leverandør « af egnet råmateriale til tværpile. Dette fremgår da også af det forhold, at en del af tværpilene i de førnæunte fund er lavet på andre typer råmateriale, se fig. 10-12.
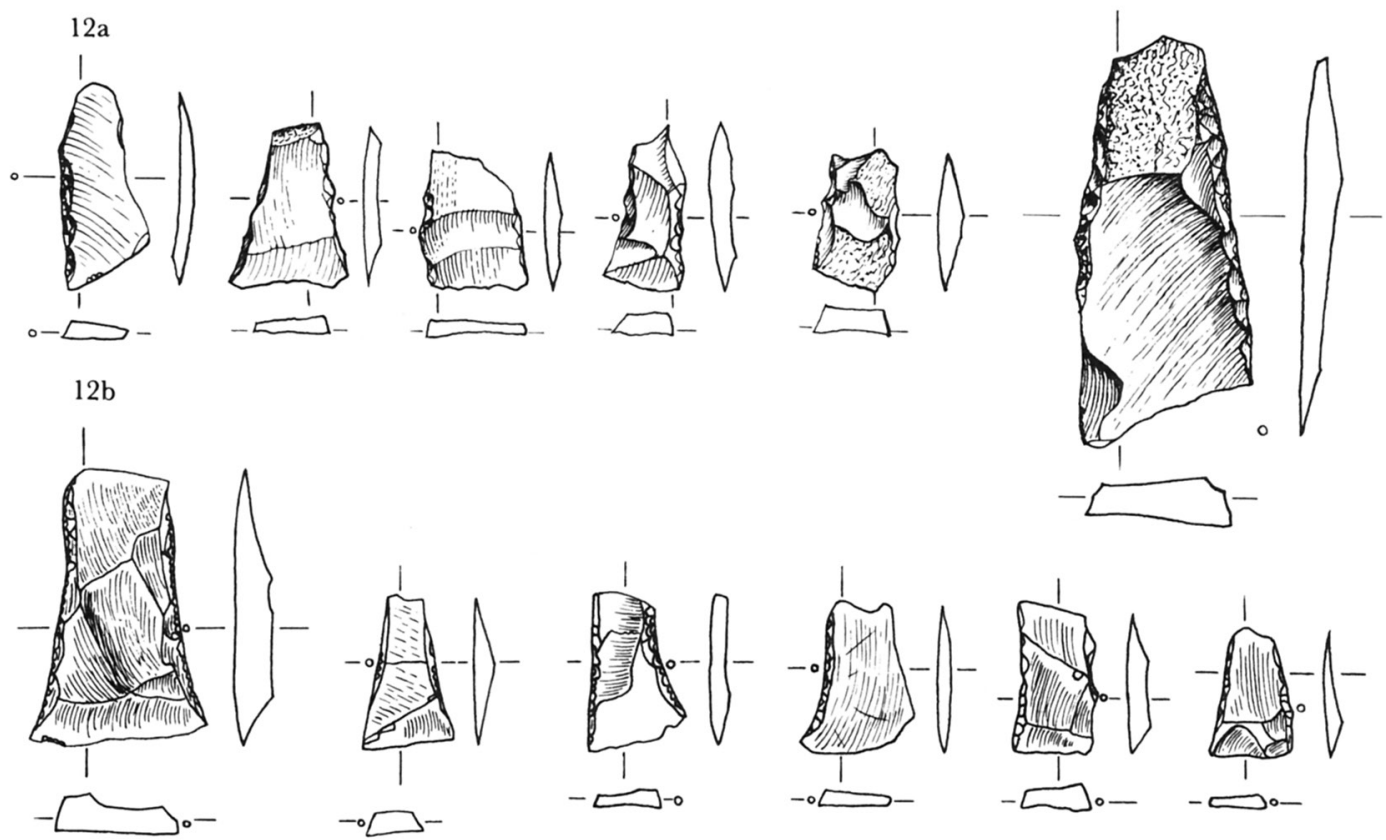

Fig. 12: Tværpile fra bopladser med »skællede skiver«. Fig. 12a fra Norslund lag 3, fig. 12b fra Norslund lag $4 \mathrm{og}$ fig. 12c fra Ø. Jølby på Mors. 3:4. Tegning: S. H. Andersen.

Transverse arrowheads from sites with scale-worked flakes. Fig. 12a from Norslund layer 3, fig. 12b from Norslund layer 4, and fig. 12c from Øster Jølby, Mors. Drawing: S. H. Andersen.

$12 \mathrm{c}$
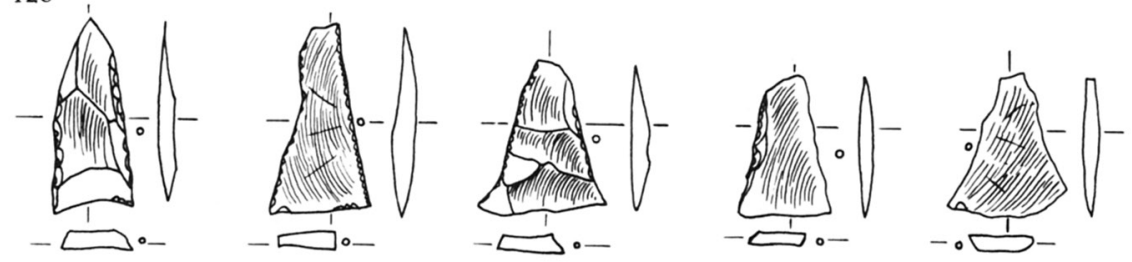

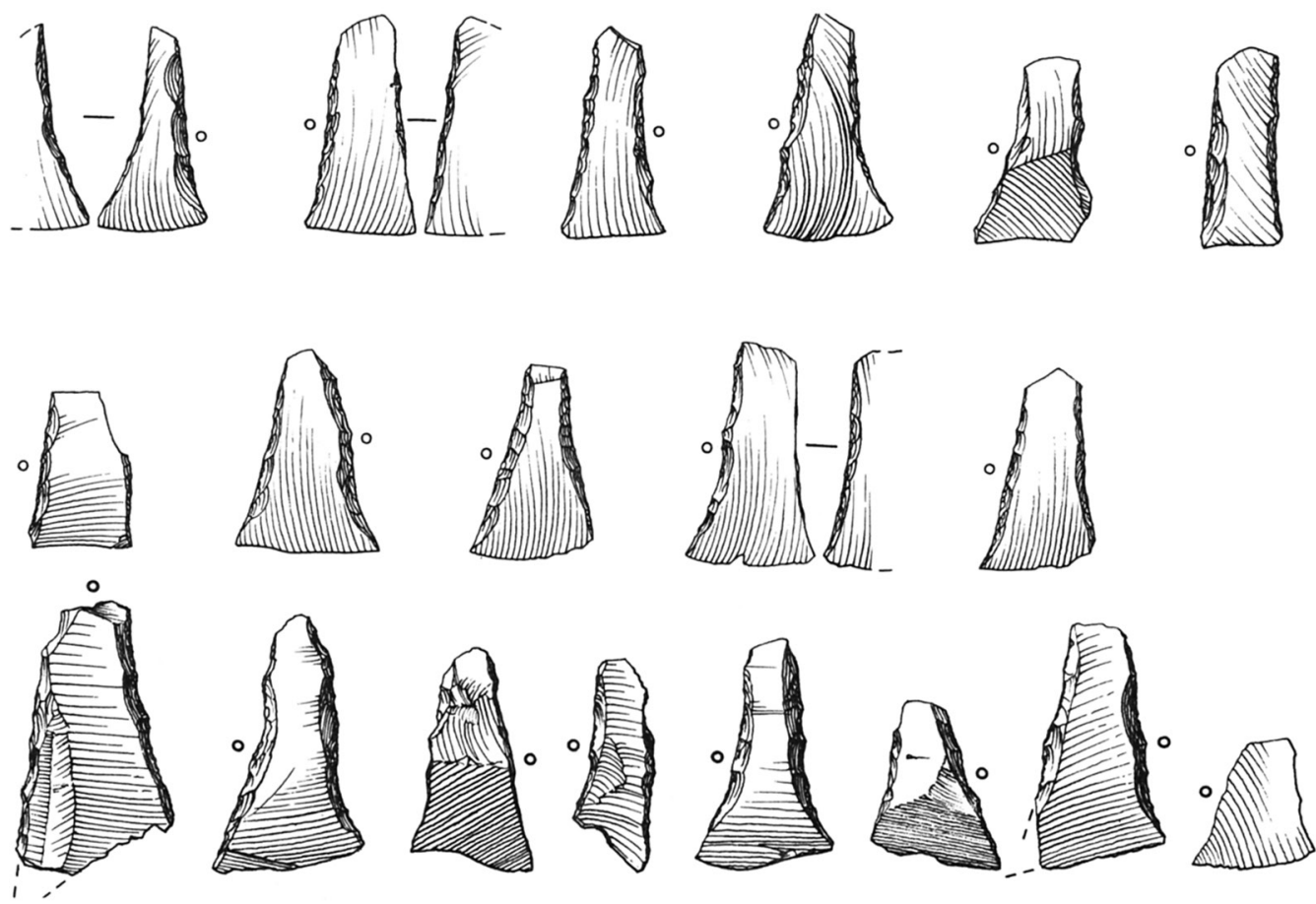

Fig. 13: Tværpile på glatsidede fliser fra Agdruplund (øverst), Brovst lag 2 og 11 (nederst). 1:1.

Tranverse arrowheads on smoothsided trimming flakes from Agdruplund (top) and Brovst layer 2 and 11 (bottom).

Fig. 14: Tværpil fremstillet af sleben, tyndnakket økse. Pilen er fundet ved Ringkloster (cf. KUML 1973-74) i den neolitiske TN-B horisont.

Transverse arrowhead made on a fragment from a polished thinbutted axe. The arrowhead was found at Ringkloster in the early neolithic B horizon (cf. KUML 1973-74).

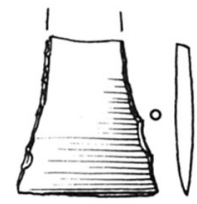

Ved Brovst kan iagttages, hvorledes de skællede skiver aftager i hyppighed opefter igennem lagserien. I det ældste lag (lag 2) er formen tilsyneladende helt enerådende, hvorefter den gradvis aftager for helt at forsvinde $\mathrm{i}$ den nedre del af lag 4.

I den yngste horisont er de skælhuggede skiver fåtallige og ikke så systematiske og ensartede i forarbejdningen som tidligere; de virker tilfældige, og man får et tydeligt indtryk af, at typen er på retur.

Tilsvarende iagttagelser er gjort ved bopladserne nær Ø. Jølby på Mors.

Samtidig med de skælhuggede skivers gradvise forsvinden, præges fundlagene af en tiltagende mængde af flade to-polede el. diskosblokke, hvis form og afslagsar tydeligt viser, at de også har været benyttet til at levere korte, tynde afslag til tværpilefremstillingen, fig. 16-17. 
Fig. 15: De forskellige trin i fremstillingen af en skælhugget skive. Først hugges skiven afkærnen (1), dernæst fjernes dens slagbuleparti ved tilhugning og retouchering fra bugsiden (2), og sluttelig fremstilles små fliser ved en eller flere afspaltninger udgående fra den tilhuggede og retoucherede kant (3).

The different stages in the production of a scale-worked flake. First the flake is removed from the core (1), then its bulb of percussion is removed with retouch from the ventral side (2), and finally small trimming flakes are produced with one or more removals emanating from the worked and retouched edge (3).
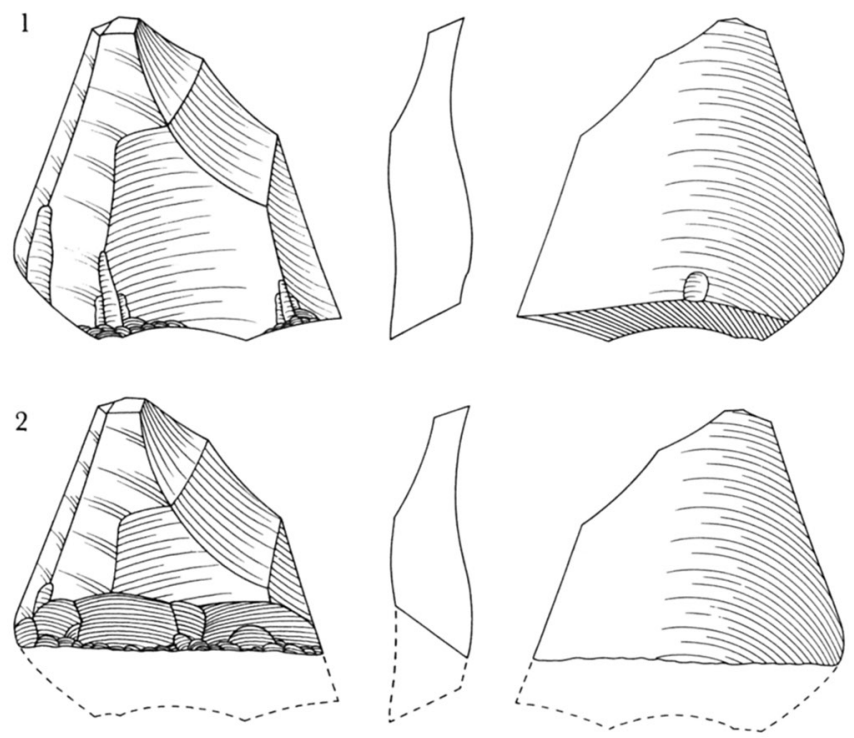

3
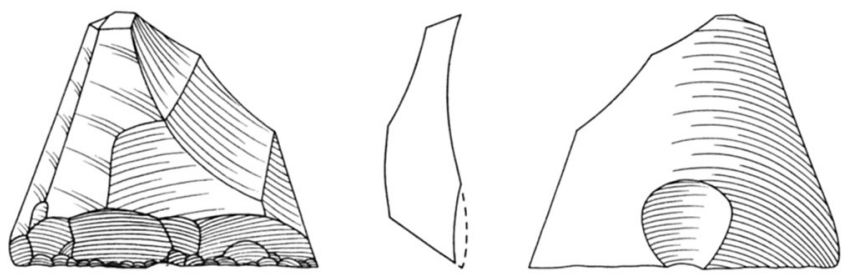

4
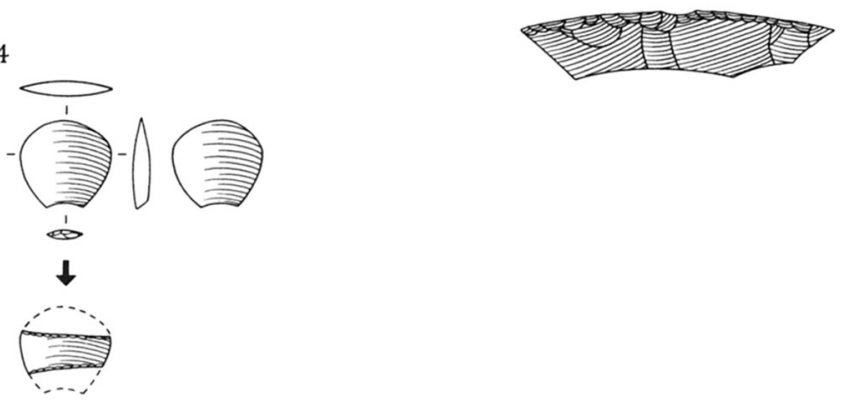

\section{Datering}

På Brovst-bopladsen er skælhuggede skiver kun fundet i lag 2, 11, 8 og 4 . Tilsvarende stratigrafiske iagttagelser er gjort ved Norslund og ved udgravninger på tidlige Ertebøllebopladser på Mors og Mols (11).

Ved Norslund, lag 3, er typen også konstateret med sikkerhed. Fra denne boplads kendes kun fă, men typiske skælhuggede skiver. Det stemmer godt overens med den omstændighed, at kun ca. $11 \%$ af tværpilene i 
dette lag er lavet af denne art råmateriale. På Norslund, lag 2, kendes formen ikke.

Typen er også påvist ved en gennemgang af fundstoffet fra Dyrholmen (12). Der blev her optalt 15 stk. typiske og 8 stk. mindre typiske skælhuggede skiver. Hertil kommer også 13 stk. tværpile, lavet af dobbeltkonvekse fliser. Næsten alle skælhuggede skiver (13 stk. ud af ialt 15 stk.) kan her henføres til zone I's område, mens formen er sjælden inden for zone II og III's område. Tilsvarende gælder, at alle de ovennævnte tværpile stammer fra zone I's område.

De øvrige jyske bopladser, hvor typen er påvist, kan ud fra typologiske studier dateres til den tidligste Ertebøllekultur (Norslund-fasen) (13), eller »den ikke-keramiske fase « af Ertebøllekulturen i Jylland.

Det hidtil ældste, sikkert daterede miljø, hvor typen er tilstede, er Brovst, lag 2-11. Lag 11 er kulstof-14 dateret til ca. $4640 \pm 110$ f.Kr. K1614 (konv. C-14 år). På dette tidspunkt er typen fuldt udviklet, cf. fig. 1; den tidligste forekomst af skælhuggede skiver må derfor antagelig dateres til perioden umiddelbart før $4700 \mathrm{f} . \mathrm{Kr}$.

Den yngste forekomst af denne type i et stratigrafisk sikkert lag er Norslund, lag 3, og Brovst, lag 4, der er kulstof-14 dateret til henholdsvis $3780 \pm 120$ (K 990) og $3660 \pm 120$ (K 1613) f. Kr. Efter dette tidspunkt er typen ikke påvist på de jyske Ertebøllebopladser, og helt nye bloktyper til fremstilling af råemner til tværpile dukker herefter op.

De nye bloktyper er først og fremmest mandel- eller diskosformede blokke og flade, topolede blokke, fig. 16-17, der tilhører perioden 3600-3200 f.Kr.

Det er således klart, at de skælhuggede skiver tilhører en ganske bestemt og afgrænset horisont $\mathrm{i}$ den jyske Ertebøllesekvens. Ud fra såvel stratigrafisk/typologiske iagttagelser som kulstof-14 dateringer af de nævnte lag, kan formens levetid dateres til perioden ca. 4600-3700 f.Kr. (udtrykt i konventionelle C-14 år).

Da typen således er tidsmæssigt begrænset, er den velegnet som kronologisk indikator - især på »åbne bopladser« (overfladefund), hvor det erfaringsmæssigt kan være svært at finde tværpile.

\section{Udbredelse}

Geografisk er typen udbredt i hele Nord- og Østjylland, fig. 18. På samtlige bopladser er de skælhuggede skiver fundet i afgrænsede lag fra den ældste Ertebøllekultur.

Hovedparten af de hidtidige bopladsfund er kystbopladser. »Skælhuggede skiver « er endnu kun påvist på én indlandsboplads: Ringkloster (14).

De skælhuggede skiver er hidtil kun påvist nord for »vippelinien«.

Det er indtil videre ikke lykkedes at påvise typen i jævngamle Ertebøllefund fra Sjælland, men også her må der tages højde for fundstoffets 
repræsentativitet. Imidlertid viser de publicerede tværpile fra tidlige, sjællandske kystbopladser, at disse tilsyneladende ikke er lavet af samme type råmateriale som beskrevet i det foregående (9).
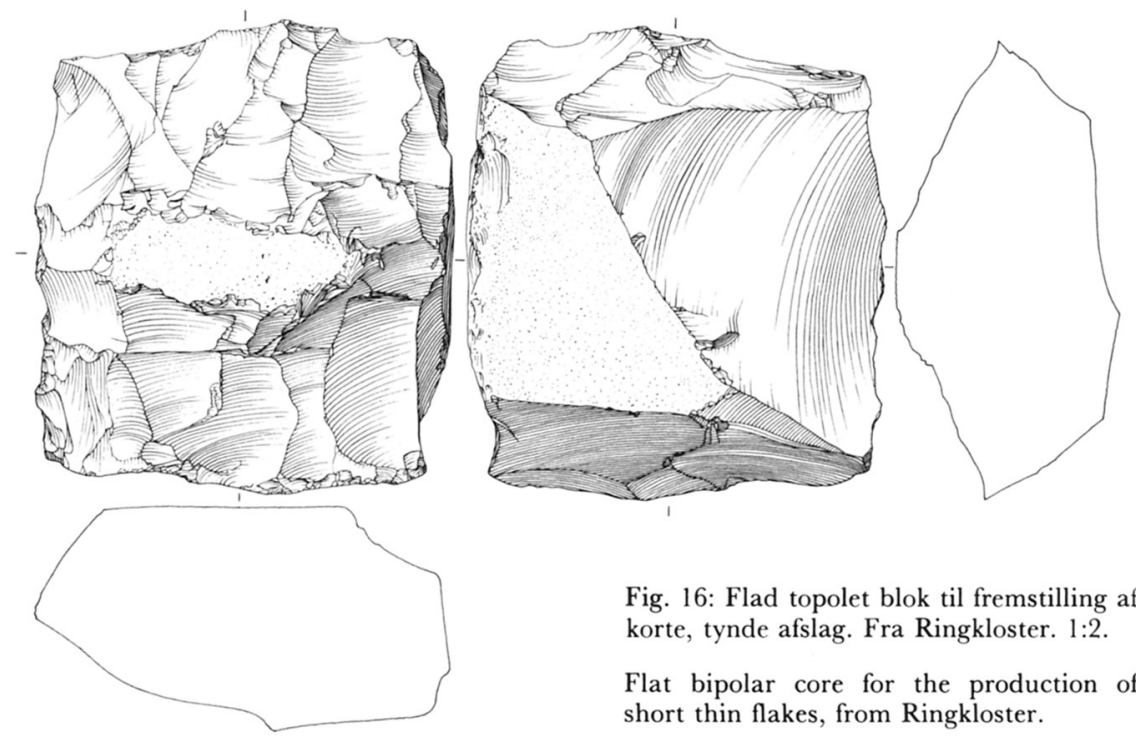

Fig. 16: Flad topolet blok til fremstilling af korte, tynde afslag. Fra Ringkloster. 1:2.

Flat bipolar core for the production of short thin flakes, from Ringkloster.

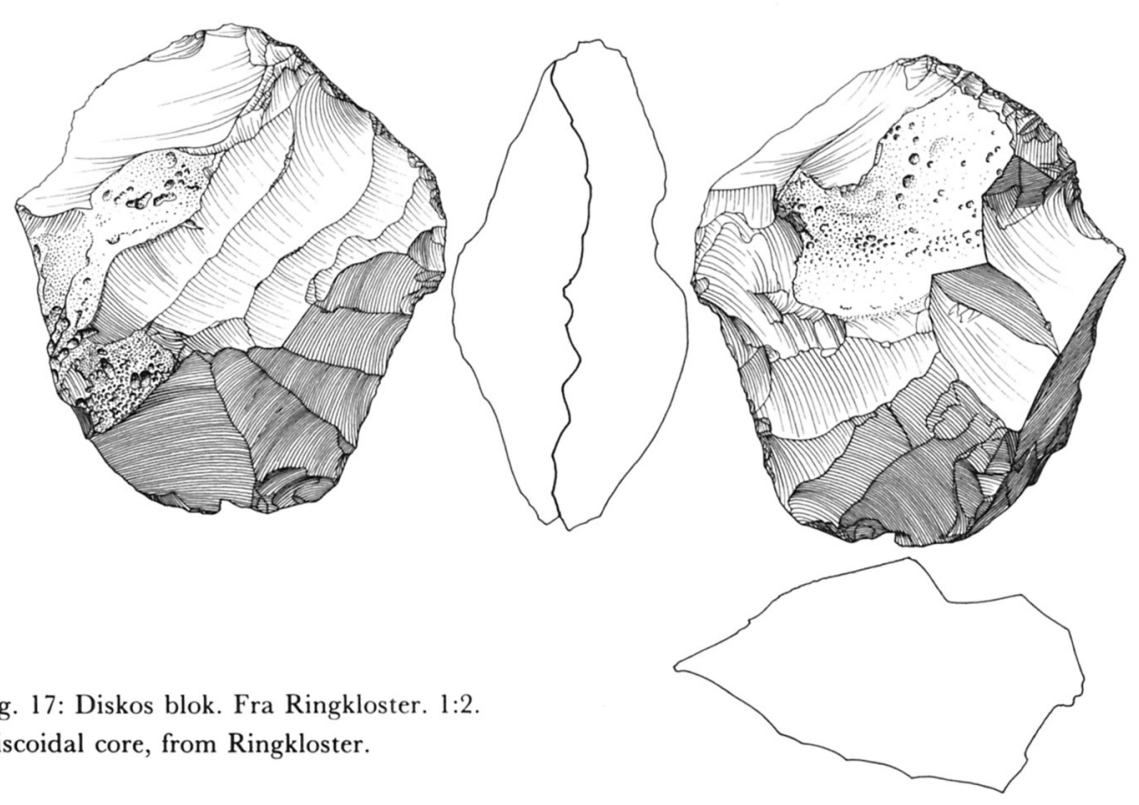

Fig. 17: Diskos blok. Fra Ringkloster. 1:2. Discoidal core, from Ringkloster. 


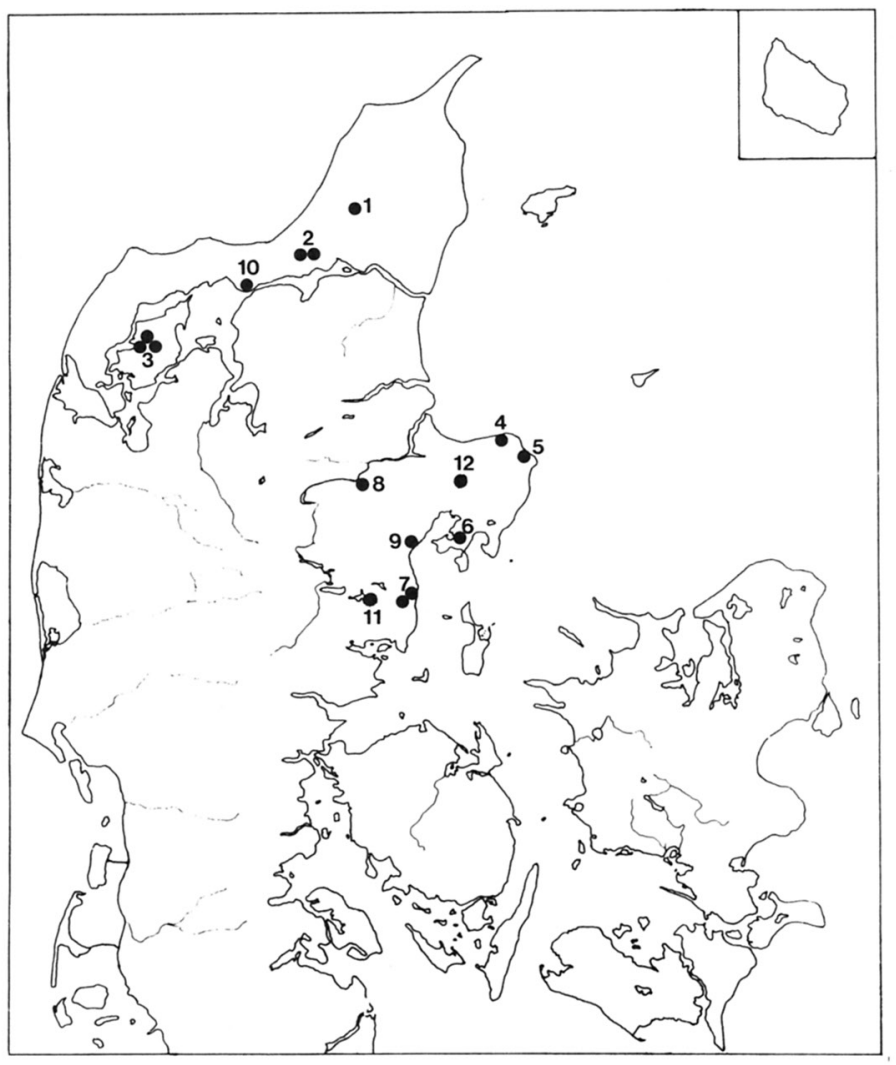

Udbredelseskort over bopladser med skællede skiver i Danmark: 1. Agdruplund, 2. bopladser ved Brovst, 3 . bopladser ved Ø. Jølby (Pismølle), Mors, 4. Birkelund, 5. Gjerrild,6. Skellerup, Knebel vig, 7. bopladser ved Norsminde fjord, 8. Brogård, 9. Sokjær, 10 . Aggersund, 11. Ringkloster, 12. Dyrholmen.

Distribution map showing sites with scale-worked flakes in Denmark.

De nuværende iagttagelser tyder således på, at der må regnes med regionale forskelle - både med hensyn til råmateriale og udformning af de ældste tværpile - mellem Vest- og Østdanmark.

Konsekvensen af disse iagttagelser er, at det fremover er nødvendigt at arbejde med lokale, typologiske udviklinger, og at der derfor må udarbejdes regionale kronologi-systemer, baseret på stratigrafiske undersøgelser inden for de to områder.

\section{Sammenfatning}

I det foregående er beskrevet en hidtil ukendt type affaldsprodukt fra fremstillingen af de ældste tværpile i Jylland. Den nye form, skælhuggede skiver kan vel bedst karakteriseres som en specialiceret »bloktype«, der kan dateres til perioden ca. 4700-3700 f.Kr. Herefter afløses den af andre specialiserede blokformer, f.eks. diskesformede, eller flade, to-polede blokke, der tilhører perioden ca. 3600-3200 f.Kr.

Studiet af Ertebøllekulturens tværpile og deres fremstillingsteknik viser, at denne kultur (iøvrigt ligesom Maglemosekulturen) producerer særlige 
blokke - udelukkende med det formål at levere egnede råemner til fremstilling af tværpile.

Under forbehold af fundstoffets repræsentativitet synes det at fremgå, at skælhuggede skiver kun optræder i den ældste Ertebøllekultur i Jylland.

Typen er herved med til at understrege forskellene mellem Ertebøllekulturen i Vest- og Østdanmark - forskelle, der tilsyneladende allerede kan spores i dens tidligste faser.

\section{KATALOG OVER BOPLADSER MED FUND AF SKÆLHUGGEDE SKIVER}

\section{Hjørring amt \\ Agdruplund. Brønderslev s., Børglum h., Hjørring a. FHM. 1681. Bopladsopsamling.}

Stort overfladefund fra boplads beliggende på gl. litorinakystlinie. Oldsager fra stor, men kortvarig bebyggelse i tidlig Ertebøllekultur (Norslund-fasen) og atter i neolitisk tid. De skællede skivers tilknytning til Ertebøllebebyggelsen er sikret på grund af klar forskel i flintens overfladeomdannelse.

Datering: Ældre Ertebøllekultur.

Upubl.

Brovst. Brovst s., Ø. Han h., Hjørring a.

FHM. 1586. Systematisk bopladsudgravning. Stort bopladsfund (kystboplads) med klar stratigrafi repræsenterende adskillige bebyggelsesfaser. Lagenes indhold af oldsager viser typologisk-kronologiske faser fra yngre Kongemose- over Ertebølle- til tidlig neolitisk Tragtbægerkultur. Skælhuggede skiver er fundet i stort tal i lag 2, 11, 8 og 4 (nedre del) repræsenterende overgangen yngre Kongemosekultur/ældste Ertebøllekultur og ældre Ertebøllekultur (Norslund-fasen).

Datering: Lagene er kulstof-14 dateret til at være yngre end el. samtidig 4610 120 (K1859) og ældre end. $3660 \pm 100$ (K-1613) (Konv. $\mathrm{C}^{14}$ ).

Litt.: S. H. Andersen: Brovst, en kystboplads fra ældre stenalder. KUML 1969. p. 67 ff.

Brovst II. Ø. Svenstrup s., Ø. Han h., Hjørring a.

FHM. 1800. Bopladsopsamling.

Mindre overfladefund fra boplads beliggende på gl. littorinakystlinie ca. $400 \mathrm{~m} \mathrm{VNV}$ for Brovst (se ovenfor).

Fundet er »rent« og repræsenterer en kortvarig Ertebøllebebyggelse; kun oldsager fra ældre Ertebøllekultur (Norslund-fasen).

Datering: Ældre Ertebøllekultur.

Upubl.

Aggersund. (Bundgård). Bejstrup s., Ø. Han h., Hjørring a.

FHM. 1870 og AHM 504. Systematisk bopladsudgravning.

Lille bopladsfund (skaldynge) repræsenterende en kortvarig bebyggelse af Ertebøllekultur svarende til Norslund lag 2 (cf. S. H. Andersen \& C. Malmros. 1965) el. Th. Mathiassens II. stadium af den jyske Ertebøllekultur (cf. Mathiassen. 1942 p. 63).

Skælhuggede skiver er fundet på sekundært leje i marint sandlag under skaldyngen, hvis ældste del er $\mathrm{C}^{14}$-dateret til 3540 110 (K- 2084) (Konv. C ${ }^{14}$ år). Sandlaget repræsenterer antagelig den højatlantiske transgression. 
Datering: De skælhuggede skiver er da ældre end, eller samtidige med den højatlantiske transgression og ældre end $3540 \pm 110 \mathrm{f.Kr}$.

Litt.: S. H. Andersen: Aggersund, en Limfjordsboplads med Ertebøllekultur. KUML. 1978. p. 7-56.

\section{Thisted amt}

Pismalle I og II (Ø. Jolby). Ø. Jølby s., Mors Nørre h., Thisted a.

FHM. 1362 og 1597. Systematisk bopladsudgravning.

Bopladsfund (kystboplads) med klar stratigrafi af flere bebyggelsesfaser. Lagenes indhold af oldsager repræsenterer en successiv typologisk-kronologisk udvikling fra yngre Kongemose- til ældre Ertebøllekultur (Norslund-fasen).

Skælhuggede skiver er fundet i stort tal i lagene, 10, 11, 12 og 18 der repræsenterer overgangen yngre Kongemose/ældste Ertebøllekultur.

Datering: Lagfølgen med skællede skiver er på denne lokalitet kulstof-14 dateret til perioden

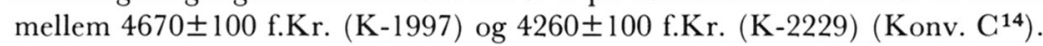

Upubl., men kort omtalt i: S. H. Andersen og C. Malmros: Norslund. En kystboplads fra ældre stenalder. KUML 1965. p. $101 \mathrm{ff}$.

Benthinesminde. Frøstrup s., Mors Sønder h., Thisted a.

FHM. 1781. Systematisk bopladsudgravning.

Bopladsfund (kystboplads) med klar stratigrafi repræsenterende flere Ertebølle-bebyggelser.

Datering: Ældre Ertebøllekultur.

Upubl.

\section{Randers amt}

Birkelund. Glesborg s., Djurs Nørre h., Randers a. Bopladsopsamling (kystboplads) fra lokalitet beliggende på gl. littorinakystlinie ved vestsiden af Bønnerup Kær.

Omlejret oldsagsmateriale. Typologiske studier viser, at fundet repræsenterer flere forskellige Ertebøllebebyggelser.

De skællede skiver kan med sikkerhed henføres til den ældste bebyggelse p.gr. af karakteren af overfladeomdannelse.

Datering: Aldre Ertebøllekultur.

Upubl. Privatsamling.

Dyrholmen. Hørning s., Sønderhald h., Randers a. NM I A. 35292. Systematisk bopladsudgravning.

Stort bopladsfund (kystboplads) med både horisontal og vertikal stratigrafi. Lagenes og områdernes indhold af oldsager repræsenterer successive typologisk-kronologiske stadier af Ertebøllekulturen.

De skælhuggede skiver findes næsten udelukkende inden for Zone I's område, men enkelte optræder dog også i Zone II.

Datering: Ældre Ertebøllekultur.

Litt.: Th. Mathiassen, M. Degerbøl ogJ. Troels-Smith: Dyrholmen. En Stenalderboplads paa Djursland. Det Kongelige Danske Videnskabernes Selskab. Arkæologisk-Kunsthistoriske Skrifter, Bd. I, Nr. 1. 1942.

Gerrild. Gerrild s., Djurs Nørre h., Randers a.

Bopladsopsamling. Stort overfladefund fra boplads beliggende på gl. littorinakystlinie. 
Oldsager fra stor, men kortvarig bebyggelse af ældre Ertebøllekultur (Norslund-fasen). Kun oldsager fra denne periode.

Datering: Ældre Ertebøllekultur.

Upubl. Privatsamling.

Brogård. Ørum s., Galten h., Randers a.

FHM 2016. Systematisk bopladsudgravning.

Bopladsfund (kystboplads) med fund fra Kongemose- og ældre Ertebøllekultur.

Datering: Ældre Ertebøllekultur.

Upubl.

Ebdrup. Ebdrup s., Djurs Sønder h., Randers a.

Bopladsopsamling. Stort overfladefund fra større boplads beliggende på littorinahavbund nær Korup å syd for Kolindsund. Omlejret oldsagsmateriale. Typologiske studier viser, at fundet består af oldsager fra ældre (Norslund-fasen) og yngre Ertebøllekultur (Dyrholmen II).

Datering: Ertebøllekultur.

Upubl. Privatsamling.

Skellerup Vig. Knebel s., Mols h., Randers a.

FHM. 1993. Systematisk bopladsudgravning.

Bopladsfund (kystboplads) med klar stratigrafi repræsenterende flere bebyggelser fra yngre

Kongemose- og ældre Ertebøllekultur (Norslund-fasen).

De skællede skiver er fundet i lag med oldsager fra ældre Ertebøllekultur.

Datering: Ældre Ertebøllekultur. Det dybeste lag C-14 dateret til $4190 \pm 95$ f.Kr. (K-1397). Upubl.

\section{Skanderborg Amt}

Ringkloster. Hylke s., Voer h., Skanderborg a.

FHM. 1592. Systematisk bopladsudgravning.

Stort bopladsfund, indlandsboplads med stratigrafiske lag repræsenterende bebyggelser fra ældre og yngre Ertebøllekultur.

Skælhuggede skiver er fundet i stratigrafisk sikre lag med oldsager fra ældre Ertebøllekultur (Norslund-fasen).

Datering: Eldre end 3660 110 f. Kr. (K-1652).

Litt.: Søren H. Andersen: Ringkloster. En jysk indlandsboplads med Ertebøllekultur. KUML 1973/74. p. $10 \mathrm{ff}$.

\section{Århus amt}

Norslund. Malling s., Ning h., Århus a.

FHM. 1375. Systematisk bopladsudgravning.

Stort bopladsfund (kystboplads) med stratigrafisk lagserie repræsenterende forskellige stadier af Ertebøllekultur.

Skælhuggede skiver er med sikkerhed fundet i lag 3 og formodentlig også lag 4, der repræsenterer ældre Ertebøllekultur (Norslund-fasen).

Datering: Samtidig med eller ældre end 3755 \pm 120 f.Kr. (K-990 og K-991), og yngre end $4470 \pm 130$ f.Kr. (K-973).

Litt.: Søren H. Andersen og C. Malmros: Norslund. En kystboplads fra ældre stenalder. KUML 1965. p. $35 \mathrm{ff}$. 
Engelsgård. Malling s., Ning h., Århus a.

FHM. 1778. Systematisk bopladsudgravning.

Bopladsfund (kystboplads) på gl. littorinakyst med marine lagserier med indlejrede oldsager repræsenterende forskellige stadier af Ertebøllekultur.

Skælhuggede skiver er fundet i lag, hvis indhold af oldsager tilhører ældre Ertebøllekultur (Norslund-fasen).

Datering: Ældre Ertebøllekultur.

Litt:: Søren H. Andersen: Et østjysk fjordsystems bebyggelse i stenalderen, Norsminde Fjord undersøgelsen.

Bebyggelsesarkæologi. Skrifter fra Institut for Historie og Samfundsvidenskab. Nr. 17, p. 18 ff. 1976.

Frederiksdal. Saxild s., Hads h., Århus a.

FHM. 1777. Bopladsopsamling.

Stort bopladsfund (kystboplads) på gl. littorinahavbund med oldsager fra ældre Ertebøllekultur.

Bopladsfundet er delvis omlejret, men repræsenterer kun én bebyggelse.

Datering: Ældste Ertebøllekultur.

Litt.: Søren H. Andersen, 1976 anf. arb.

Soker (Lystrup). Vejlby s., Hasle h., Århus a.

Bopladsopsamling. Stort bopladsfund (kystboplads) beliggende på gl. littorinakyst med oldsager fra Ertebøllekultur.

Typologiske studier viser, at flere Ertebøllefaser, både ældre og yngre E., er tilstede i fundet, men sammenblandede p.gr. af markdyrkning.

Datering: Ertebøllekultur.

Upubl. Privatsamling.

\section{SUMMARY}

The scale-worked flakes - a newly-discovered artifact type from the early Ertebølle culture of Western Denmark.

The transverse arrowhead occupies a characteristic and conspicious place among the implements of the Ertebølle culture, and it is thus natural that both the implement and its method of production have been the basis for several thorough discussions in the archaeological literature. (1)

Widespread excavation in the last few years of Ertebølle sites in Jutland has resulted in an important increase in our knowledge of both the early transverse arrowhead types and their method of production (2).

During excavation of the Brovst settlement (3) a characteristic artifact was noticed for the first time in the oldest levels (Levels 2 and 11 ); this artifact type has never before been described in the literature.

This artifact, figs. 1 to 10 , occurred in such large numbers and with such a uniform morphology as to rule out the possibility of chance, and appears as a regularly produced type. The artifact, termed 'scale-worked flakes', has since been observed on many settlements belonging to the oldest phase of the Ertebølle culture in western Denmark.

The artifacts themselves are crude, thick, struck flakes with a regularly worked and retouched edge on the bulb of percussion end, fig. 1-10. This edge is usually straight, but can also be convex. 
The working is always normal and always results in the removal of most of the original bulbof percussion end of the flake, fig. 1. On all the implements there are also scars indicating the removal of thin, scale-like flakes from the ventral surface, fig. 1-10. These scars appear only on the ventral surface and always emanate from the retouched edge, fig. 1.

The form and working of the described pieces shows that they form an artifact type clearly distinct from previously known and described artifacts from the Danish mesolithic.

A detailed analysis of the individual stages of preparation and utilization of these 'scaleworked flakes' shows that they are in fact the waste products resulting from the production of one or more small thin scale flakes from the ventral surface of the scale-worked flake itself. The retouched edge functioned as a prepared striking platform for the subsequent removal of the scale flakes from the ventral surface of the scale-worked flake. In fig. 5a reconstruction of the complete sequence of working is attempted.

The question remains as to what use the scale flakes were put. They are round or oval, and have a biconvex or lense shaped cross section; the side surfaces are perfectly smooth, fig. 11. It is evident that the symmetrical lense shaped cross section and the smooth surfaces were regularly sought after attributes. It was these needs which determined that the scale flakes were produced from the bulb of percussion of the scale-worked flakes; only here was the surface sufficiently convex and without irregularities.

The frequent appearence of 'scale flakes' and a count of the scars resulting from their removal on the scale-worked pieces' ventral surface shows that scale flakes must have been very common on settlements.

Small flakes with the required shape and form are present on settlements on which 'scaleworked flakes' have been observed; they are not known from sites from which 'scale-worked flakes' are absent. Small flakes are shown in fig. 11.

However the number of scale flakes is much smaller than would be expected from a count of the scars on the 'scale-worked flakes.' This can only be due to the fact that the scale flakes must have been worked further.

As a large proportion of the transverse arrowheads from the earliest Ertebølle finds are made from small, disc shaped flakes with a lense shaped cross section and smooth side surfaces, there are grounds for assuming that mass production of small flakes was intended for transverse arrowhead manufacture. This method of manufacture is also known from a much later period, namely the Early Neolithic, when flakes of thinbutted polished axes were used for transverse arrowhead production, fig. 14.

Thus the 'scale-worked flakes' must be regarded as a specialised and characteristic waste product from the production of transverse arrowheads.

During the excavation of Brovst, 'scale-worked flakes' were only found in the oldest levels, i.e. levels 2, 11, 8 and the lower part of 4 (3). Corresponding stratigraphic observations have been made at other early Ertebølle settlements. The 'scale-worked flakes' belong to a definite 'horizon' within the early Ertebølle culture, and may be dated to ca. $4600-3800$ B.C. (conventional C14 years). 'Scale-worked flakes' seem to appear at the transition from the Kongemose to the Ertebølle cultures, and to be in use throughout the entire Norslund phase of the Ertebølle culture, after which they disappear, being replaced by other core types, for example the discoidal core, fig. 17.

Geographically the artifact type is only known from Jutland, fig. 18, as well on inland and coastal settlements. The type is not known from eastern Denmark and thus helps underline regional differences between the early Ertebølle culture of east and west Denmark.

Soren H. Andersen

Aarhus Universitet, Moesgård

Tegning: Orla Svendsen

Oversattelse: Peter Rowley-Conwy 


\section{NOTER}

1) F.eks. A. P. Madsen, Sophus Müller m.fl., Affaldsdynger fra Stenalderen i Danmark, 1900, s. 49. Mathiassen, Th.: Gudenaa-Kulturen. En mesolitisk Indlandsbebyggelse i Jylland. Aarb. f. nord. Oldk. og Hist. 1937, s. 93 ff. Becker, C. J.: En Stenalderboplads paa Ordrup Næs i Nordvestsjælland. Bidrag til Spørgsmaalet om Ertebøllekulturens Varighed. Aarb. f. nord. Oldk. og Hist. 1939, s. 245 ff. Mathiassen, Th.: Danske Oldsager. I. Ældre Stenalder. 1948, s. 27. Andersen, S. H. og C. Malmros: Norslund. En kystboplads fra ældre stenalder. KUML 1965, s. 48 ff.

2) F.eks. Andersen, S. H. og C. Malmros, 1965, anf. arb. s. 54. Andersen, S. H.: Ringkloster. En jysk indlandsboplads med Ertebøllekultur. KUML 1973/74, s. 55 og fig. 46.

3) Andersen, S. H.: Brovst, en kystboplads fra ældre stenalder. KUML 1969, s. 67 ff.

4) Forhistorisk Museum j.nr. 1362 og 1567. (Upubliceret). Systematisk udgravet bopladsfund med lag fra yngre Kongemosekultur og ældre Ertebøllekultur. Kort omtalt i: Andersen, S. H. og C. Malmros 1965 anf. arb. s. 101-102.

5) Se f.eks. Tixier, J.: Typologie de L’Épipaleolithique du Maghreb. Mémoires du Centre de Recherches Anthropologiques, Préhistoriques et Ethnographiques. Alger II, 1963, s. 30, fig. 3.

6) Becker, C. J.: Maglemosekultur paa Bornholm. Aarb. for nord. Oldk. og Hist. 1951, s. 126.

7) Andersen, S. H.: 1969 anf. arb.

8) Andersen, S. H. og C. Malmros: 1965, anf. arb. s. 35 ff.

9) Westerby, E.: Stenalderbopladser ved Klampenborg 1927, fig. 22.

Malmros, C.: Vejlebro - en stenalderboplads ved Arrefjorden. Fra Nationalmuseets Arbejdsmark 1975, fig. 5, nr. a-f og fig. 8, nr. a-b.

10) Skaarup, J.: Stengade. Ein langeländischer Wohnplatz mit Hausresten aus der frühneolithischen Zeit. 1975, s. 129, abb. 56, nr. 4.

En teknik meget lig den her beskrevne synes at kunne spores i hele tidlig-og mellemneolitisk tid. Forfatteren har ved forskellige lejligheder set grove skiveafslag med skællet behugning på bugsiden fra tidlig-og mellemneolitiske bopladsfund. På de neolitiske skiver med skælafhug er disse foretaget langs sidekanterne.

11) Skellerup Enge. Forhistorisk Museum j.nr. 1993. Prøvegravning (upubliceret). I en marin lagserie med oldsager fra Yngre Kongemosekultur til tidlig Ertebøllekultur blev der kun fundet "skællede skiver" i lagene tilhørende den ældste Ertebøllekultur.

12) Mathiassen, Th., Degerbøl, M. og J. Troels-Smith: Dyrholmen. En Stenalderboplads paa Djursland. Det Kongelige Danske Videnskabernes Selskab. Arkæologisk-Kunsthistoriske Skrifter, Bind I, Nr. 1, 1942.

De i teksten nævnte stykker er fundet under en kursorisk gennemgang af materialet fra Dyrholmen i Nationalmuseets 1. Afds. magasiner. Arkiveret under mus. nr. NM I, A.35292. De skællede skiver var her katalogiseret under betegnelsen "skiveskrabere», "knuder» etc.

13) Andersen, S. H. og C. Malmros: 1965, anf. arb. s. 100.

14) Andersen, S. H. 1973/74 anf. arb. s. 55 og fig. 45 a og k.

Allerede på et tidligt tidspunkt af undersøgelsen blev denne tværpil-type fundet ved udgravningerne af bopladsområdet på fast land. Først i de seneste år er formen også påvist i et sikkert lag i den tilgrænsende mose. 